\title{
UTILIZING SUMMATIVE TEST FOR IMPROVING THE QUALITY OF TEACHING AND LEARNING - A DIRECTION OF APPLYING FORMATIVE ASSESSMENT IN HIGH SCHOOL
}

\author{
Duy Duc Phan ${ }^{1,+}$, \\ Yen Thi Hai Nguyen ${ }^{2}$
}

\author{
Article History \\ Received: June 3, 2019 \\ Accepted: July 25, 2019 \\ Published: September 30, 2019
Keywords
Formative assessment, tests, improving quality, teaching and learning, Biology
teaching

\author{
${ }^{1}$ University of Education - Hue University, Vietnam; \\ ${ }^{2}$ University of Education - Danang University, Vietnam \\ ${ }^{+}$Corresponding author $\bullet$ Email: duy1264@gmail.com
}

\section{INTRODUCTION}

Assessment is closely associated with teaching and learning process. Many studies have shown that the way of practicing assessment affects significantly to what and how students learn (Baartman, L. K. et al., 2006). If the assessment is for grading purposes only (summative assessment), students tend to focus on learning the knowledge taught in class, learning what is reviewed to achieve high scores. According to Hayden \& Le, T. N. L. (2013), the pressure to achieve outstanding test results makes students focus only on learning the content of knowledge. Consequently, students lose interest in learning and become passive one (Hayden \& Le, T. N. L., 2013). In contrast, if assessment generates valuable feedbacks to help not only teachers but also students upgrading teaching methods and adjusting learning activities (formative assessment), teaching and learning process becomes more grossly effective (Black, P. \& Wiliam, D., 1998). In teaching Biology, many studies demonstrated that the quality of teaching process, student's thinking and academic achievement are positively influenced by formative assessment (Gioka, O., 2007; Granbom, M., 2016). Moreover, the combination of teaching and assessing, especially formative assessment, can improve effectively teaching and learning quality, students' interest and competency in learning. Therefore, strengthening the implementation of formative assessment is an urgent requirement in the trend of shifting from content - based education to competency - based education in Vietnam today.

This paper discusses on the formative assessment practice in real -context teaching in Vietnam. We present some implementation measures to use summative tests for improving Biology teaching and learning quality in high school.

\section{LITERATURE REVIEW}

Many researchers studied the nature and practice of formative assessment in real context (Bell, B. \& Cowie, B., 2001; Black, P. \& Wiliam, D., 1998; Popham, W. J., 2008; Sadler, D. R., 1989). These studies reckoned that, feedback is an extremely crucial core of formative assessment, received and used by learners and teachers to adjust and improve the quality of teaching process. For students, feedback helps shortening the gap between the current level and the expected goals (Sadler, D. R., 1989). Any assessment activities, thus, can perform formative assessment if it creates valuable feedbacks for improving the quality off teaching and learning process (Black, P. \& Wiliam, D., 1998).

Real teaching context in Vietnam has witnessed the prevalence of summative assessment. Assessment activities has revealed a lack of diversity method and systematic, mostly only performing the academic achievement of students (Dao, H. M. et al., 2013; Hayden \& Le, T. N. L., 2013). In that context, in order to facilitate assessment activities in performing the function of supporting and improving teaching and learning quality, in addition to changing assessment methods, teachers can take advantage of summative tests to enhance the quality of students' learning. 


\section{RESEARCH METHODS AND RESULTS}

\subsection{Research methods}

In this paper, we analyzing method and synthesizing theory method, systematizing theory to study integrated teaching. We also use the applied research method to apply the theory into practice.

\subsection{Basis strategies in conducting formative assessment}

Three key processes to implement formative assessment:

- Establishing the desirable targets in student's learning.

- Determining where the learners are in their learning (compared to the targets).

- Establishing what needs to be done to get them there.

In particular, the teacher is responsible for designing and establishing effective learning environment, and the learner is responsible for actively learning in that environment. Both the teacher and the learner are those who are jointly responsible and adjust each other for effective learning. The role of teachers and learners in the above three strategies are shown as follows:

Table 1. Basic strategies for implementing formative assessment in teaching

\begin{tabular}{|c|c|c|c|}
\hline & $\begin{array}{c}\text { Establishing desirable } \\
\text { targets }\end{array}$ & $\begin{array}{c}\text { Determining where the learner } \\
\text { is right now }\end{array}$ & $\begin{array}{l}\text { Establishing what needs } \\
\text { to be done }\end{array}$ \\
\hline Teacher & $\begin{array}{l}\text { Clarifying targets and criteria } \\
\text { for success }\end{array}$ & $\begin{array}{l}\text { Designing and organizing class } \\
\text { discussion and other learning tasks } \\
\text { to collect valuable evidence related } \\
\text { to the current level of students } \\
\text { compared with the targets. }\end{array}$ & $\begin{array}{l}\text { Providing feedbacks that move } \\
\text { learners forward }\end{array}$ \\
\hline Learner & $\begin{array}{l}\text { Understanding targets and } \\
\text { criteria for success }\end{array}$ & \multicolumn{2}{|c|}{ Activating students as the owner of their own learning } \\
\hline Peer & $\begin{array}{l}\text { Understanding and sharing } \\
\text { targets and criteria for success }\end{array}$ & \multicolumn{2}{|c|}{ Activating students as the guider for others learning } \\
\hline
\end{tabular}

Particularly, implementing formative assessment could be specified by five key strategies as follow:

(1) Clarifying and sharing targets and criteria for success.

(2) Designing and organizing class discussion and other learning tasks to collect valuable evidence related to the current level of student compared with the targets.

(3) Providing feedbacks that move learners forward.

(4) Activating students as the guider for others learning.

(5) Activating students as the owner of their own learning.

As a result, any other kinds of assessment activities that meet these strategies can become formative assessment. Using appropriately summative tests (or more properly, tests designed primarily to serve a summative function) can elicit valuable feedbacks moving learning forward. Because feedbacks obtained from summative tests will help learners identifying which issues are important in a particular subject, thereby they understand more about the goals and criteria for success.

\subsection{Using summative tests to promote the quality of students' learning}

Based on the practical strategies of formative assessment, we determine four key principles when using summative tests for enhancing the quality of students' learning:

(1) Learners need to understand target and criteria assessment.

(2) Students should be involved in a review result of the test so that they can plan to adjust their learning more effectively.

(3) Students should be encouraged to raise questions and mark their test by themselves. These help students clearly understanding assessment process and establishing proper learning strategies to upgrade their learning.

(4) Self and peer - assessments need to be strengthened to help students deeply comprehending targets and criteria for success.

Based on these principles, we propose three measures for using summative test in order to enhance learning quality. Teachers should combine all three measures to bring about effective improvement for the quality of students' learning. 
Sharing targets and criteria for success to students:

Teachers notify assessment targets and criteria with students in revision class. Through comparing current level of students' learning with expected targets, students obviously identify their shortcomings and establish appropriate solutions. Moreover, assessment criteria help students reviewing more effectively, thus achieving better assessment result. The criteria can be presented in the form of rubric, not only showing the criteria but also expressing the expected level of each criterion.

An example of the rubric and assessment goals that teachers share with students in a revision class (before a final test of first term, Biology program, grade 10):

\section{Table 2. Example of assessment targets and criteria in revision sheet}

\section{ORIENTED REVISON PAPER}

Exam for the final first semester, Biology program (grade 10)

\section{Methods}

The test consists of multiple-choice questions (accounting for 60\% of the total score) and the essay questions (accounting for $40 \%$ of the total score).

2. Assessment objectives

2.1. Knowledge

- Presenting the biological structure and role of carbohydrates, lipids, proteins and nucleic acids in cell.

- Describing the external and internal structure of a typical cell.

- Differentiating prokaryotic cell from eukaryotic cell.

- Distinguishing plant cell and animal cell.

- Presenting the structure and function of the cell nucleus and organelles (Mitochondria, Chloroplasts, Endoplasmic reticulum, Golgi), and cell membrane.

- Differentiating active and passive transport, exemplary and intracellular transport.

- Presenting the structure of enzymes, the role of enzymes to the cell and energy metabolism activities of cells.

- Explaining the effect of factors on enzyme activity (through practical examples).

- Presenting briefly the stages of photosynthesis and cellular respiration.

2.2. Skills

- Conducting fluently thinking skills: comparing and analyzing.

- Presenting an issue in written language.

3. Assessment criteria (for essay questions)

\begin{tabular}{|c|c|c|c|c|}
\hline Criteria & $\begin{array}{c}4 \\
\text { (Outstanding) }\end{array}$ & $\begin{array}{c}3 \\
(\text { Good })\end{array}$ & $\begin{array}{c}2 \\
\text { (Needs } \\
\text { improvement) }\end{array}$ & $\begin{array}{c}1 \\
\text { (Incomplete) }\end{array}$ \\
\hline $\begin{array}{c}\text { Knowledge } \\
\text { content }\end{array}$ & $\begin{array}{l}\text { Completely and } \\
\text { accurately answer all } \\
\text { knowledge required } \\
\text { by questions }\end{array}$ & $\begin{array}{l}\text { Accurate knowledge } \\
\text { expressed in all answers. } \\
\text { However, missing } 1 \text { - } 2 \\
\text { unimportant knowledge } \\
\text { contents required by } \\
\text { questions. }\end{array}$ & $\begin{array}{l}\text { Showing important } \\
\text { knowledge, } \\
\text { however, 3-5 } \\
\text { knowledge contents } \\
\text { are missing or } \\
\text { inaccurate }\end{array}$ & $\begin{array}{l}\text { Many (above 5) } \\
\text { knowledge } \\
\text { contents are } \\
\text { inaccurate or } \\
\text { missing. }\end{array}$ \\
\hline $\begin{array}{l}\text { Arguing and } \\
\text { analyzing }\end{array}$ & $\begin{array}{l}\text { The information } \\
\text { given is organized } \\
\text { logically, tightly } \\
\text { linked. }\end{array}$ & $\begin{array}{l}\text { The information given is } \\
\text { organized logically. } \\
\text { There are } 1-2 \text { points that } \\
\text { lack consistency or lack } \\
\text { of tight links }\end{array}$ & $\begin{array}{l}\text { There is a lot of } \\
\text { unclear information, } \\
\text { not related to the } \\
\text { theme of questions. } \\
\text { The arguments are } \\
\text { inconsistent and lack } \\
\text { of links. }\end{array}$ & $\begin{array}{l}\text { The information } \\
\text { given is completely } \\
\text { irrelevant to the } \\
\text { topic. }\end{array}$ \\
\hline Presenting & $\begin{array}{l}\text { There are absolutely } \\
\text { no spelling and } \\
\text { grammar errors }\end{array}$ & $\begin{array}{l}\text { There are no more than } 3 \\
\text { spelling or grammar } \\
\text { errors }\end{array}$ & $\begin{array}{l}\text { There are more than } \\
4 \text { spelling or } \\
\text { grammar errors }\end{array}$ & $\begin{array}{l}\text { Lots of spelling or } \\
\text { grammar errors }\end{array}$ \\
\hline
\end{tabular}


Conducting effectively the revision class:

- Using "traffic light" method: The teacher provides a list of keywords or questions related to the upcoming test. Students are responsible for marking green ticks on the understood contents and red ones on the confusing knowledge. In addition, students are asked to recall presented questions in previous lessons or tests for the red knowledge area. They after that study textbooks, documents or discuss with classmates to clarify knowledge content. This activity helps learners not only self-assessing and improve their weakness but also reviewing learned knowledge. "Traffic light" method can be done in revision classes or at home before conducting a test.

- Learners make test questions by themselves: Before performing each test, students are oriented to create expected test questions, then doing those by themselves or with others. This conclusion based primarily on the comparison between the experimental group and the control group with normal revision. In addition, questions play extremely crucial role for stimulating positivity, thinking ability of learners. Moreover, answering their own questions or others' questions helps students profoundly comprehending the learned knowledge and clarifying ambiguous issues.

The following is an example of revision worksheet for the first term test in Biology program (grade 10):

Table 3. A revision worksheet for the test

\section{REVISION WORKSHEET}

For the first term test in Biology program (grade 10)

For each given keyword, you have to mark on the suitable level of comprehension for yourself (For the Limited understanding level, you must to specify problems that you confuse and need assistance. Making yourself questions that may be relevant to given keywords (checking stick * in the question you need support to answer).

\begin{tabular}{|c|c|c|c|c|}
\hline \multirow[b]{2}{*}{ Key words } & \multicolumn{3}{|c|}{ Levels of understanding } & \multirow{2}{*}{$\begin{array}{l}\text { Self-assessing } \\
\text { questions }\end{array}$} \\
\hline & $\begin{array}{c}\text { Complete } \\
\text { understanding }\end{array}$ & $\begin{array}{c}\text { Limited } \\
\text { understanding }\end{array}$ & $\begin{array}{c}\text { No } \\
\text { understanding }\end{array}$ & \\
\hline \multicolumn{5}{|l|}{ Chemical component of cells } \\
\hline \multicolumn{5}{|l|}{$\begin{array}{l}\text { Structure of cells: } \\
\text { - Prokaryotes, Eukaryotic cells } \\
\text { - Plant cells, animal cells } \\
\text { - Cell membrane structure } \\
\text { - Cell nuclear structure } \\
\text { - Organelles structure }\end{array}$} \\
\hline \multicolumn{5}{|l|}{ Cell membrane transport } \\
\hline \multicolumn{5}{|l|}{$\begin{array}{l}\text { Enzyme: } \\
\text { - Structure } \\
\text { - Function } \\
\text { - Factors affecting enzyme activity }\end{array}$} \\
\hline \multicolumn{5}{|l|}{ ATP (structure, function) } \\
\hline \multicolumn{5}{|l|}{$\begin{array}{l}\text { Material and energy transformation } \\
\text { in cell }\end{array}$} \\
\hline \multicolumn{5}{|l|}{ Photosynthesis } \\
\hline Cellular respiration & & & & \\
\hline
\end{tabular}

Discussing test result:

Normally, teachers write comments on student's test paper for their performance. However, most of those comments are general and unspecified like "Your writing is very good" or "Many mistakes in test performing, you need more effort". These comments undoubtedly lead to learners being confused or unaware of their own shortcomings. Therefore, in addition to specifying test comments, teachers should spend time on conducting discussion class to explicit test result in detail. Below are some suggestions for organizing effectively discussions of the test results:

- Implementing self-assessment and peer-assessment: Students compare carefully their test result with assessment criteria (offered in the revision class) in order to determine unsatisfied problems in the test. Thanks to this comparison, students identify the cause of determined problems and propose properly solutions for their learning improvement. This activity should be conducted with two students sitting at the same table. First, students self-assess and peer-assess in a detail to find out their own problems and partners' one. After that, learners discuss explicitly with their partner for fixing 
problems. During discussion time, teachers are responsible for observing and monitoring how learners look at problems. This follow-up activity helps students to be more oriented in identifying precisely the exist problems and finding appropriately solutions. Below is example worksheet can be applied for the assessment of test results:

Table 4. The sample of the test results assessment form

\section{TEST RESULT ASSESSMENT WORKSHEET}

For the first term test in Biology program (grade 10)

Based on comparing the test results and assessment criteria, you discuss with partner to determine your problem, causes and solutions.

\begin{tabular}{ccccc}
\hline Serial & $\begin{array}{c}\text { Problems } \\
(\text { Self-assessing })\end{array}$ & $\begin{array}{c}\text { Problems } \\
(\text { Peer-assessing) }\end{array}$ & Causes & Solutions \\
\hline 1 & & & \\
\hline 2 & & & \\
\hline$\ldots$ & & & \\
\hline
\end{tabular}

- Conducting whole-class discussion: Based on analyzing test results of whole class, teachers determine questions that most of students answer incorrectly. This activity focuses on helping learners not only answer those questions perfectively but also improve their learning quality and thinking ability. Discussion effectiveness derives from the organization and orientation of teachers. Specifically, teachers encourage learners presenting possible causes related to errors in each test answer. Additionally, teachers also point out what needs to be improved in learning styles, problem solving thinking and provide students with criteria for a quality answer.

\section{DISCUSSION AND CONCLUSION}

The classification of assessment into either summative or formative assessment must be based on its purpose (Wiliam, D. \& Black, P., 1996). Any assessment tools can perform formative assessment if it generates information to improve the quality of learning. Specifically, test on the one hand is a tool to effectively assess student's learning outcomes, on the other hand can also be a valuable information source for both teachers and students in improving teaching and learning quality. Exploiting the potential of the test for formative assessment extremely depends on how the teacher organizes assessment activities and the efforts of the learners themselves. Last but not least, we are convinced by Perrenoud's statement: "Every teacher who wants to practice formative assessment in the classroom must restructure their own teaching style to counteract and change the existing habits of students" (Black, D. \& Wiliam, P., 1998).

\section{REFERENCES}

Baartman, L. K. et al. (2006). The wheel of competency assessment: Presenting quality criteria for competency assessment programs. Studies in Educational Evaluation, 32(2), 153-170.

Bell, B., \& Cowie, B. (2001). The characteristics of formative assessment in science education. Science education, $85(5), 536-553$.

Black, P., \& Wiliam, D. (1998). Assessment and Classroom Learning. Assessment in Education: Principles, Policy \& Practice, 5(1), 7-74. doi: 10.1080/0969595980050102

Dao, H. M. et al. (2013). The Study of Application of the Assessment Techniques in Classrooms for Secondary Education in Vietnam. VNU Journal of Science, Educational Research, 29(2), 10-23.

Gioka, O. (2007). Assessment for learning in biology lessons. Journal of biological education, 41(3), 113-116.

Granbom, M. (2016). Formative Assessment and Increased Student Involvement Increase Grades in an Upper Secondary School Biology Course. Journal of biological education, 2, 185-195.

Hayden, M. \& Le, T. N. L. (2013). Vietnam: the education system - a need to improve quality. In LP Symaco (ed.), Education in south-east Asia, Bloomsbury Academic, London, 260-277.

Popham, W. J. (2008). Transformative Assessment. Alexandria, Virginia USA: Association for Supervision and Curriculum Development.

Sadler, D. R. (1989). Formative assessment and the design of instructional systems. Instructional science, 18(2), 119144.

Wiliam, D., \& Black, P. (1996). Meanings and consequences: a basis for distinguishing formative and summative functions of assessment? British Educational Research Journal, 22(5), 537-548. 